Dudeja, S., Bhattacherjee, A. B. and Chela-Flores, J. (2012) Antarctica as model for the possible emergence of life on Europa. In: Life on Earth and Other Planetary Bodies. A. Hanslmeier, S. Kempe and J. Seckbach (eds.). Cellular Origin and Life in Extreme Habitats and Astrobiology, Springer, Dordrecht, The Netherlands. In press.

\title{
ANTARCTICA AS MODEL FOR THE POSSIBLE EMERGENCE OF LIFE ON EUROPA
}

\author{
SUMAN DUDEJA ${ }^{1}$, ARANYA B. BHATTACHERJEE ${ }^{2}$, \\ JULIAN CHELA-FLORES ${ }^{3,4}$ \\ ${ }^{I}$ Department of Chemistry, ARSD College, University of Delhi, New \\ Delhil10021, India. \\ ${ }^{2}$ Department of Physics, ARSD College, University of Delhi, New \\ Delhil10021, India. \\ ${ }^{3}$ The Abdus Salam International Centre for Theoretical Physics, Strada \\ Costieria 11, 34014 Trieste, Italy. ${ }^{4}$ Instituto de Estudios Avanzados, \\ Caracas 1015A, Republica Bolivariana de Venezuela.
}

\begin{abstract}
Summary. We highlight three aspects of life on the Antarctic continent that are relevant for astrobiology: Firstly, the poorly known ecosystem of Lake Vostok; secondly, the ecosystems that are well-understood in the dry valley lakes of Victoria Land, especially in Taylor Valley and, finally, the recently discovered microbially-produced patches in Blood Falls. These three environments are appropriate models of possible habitats that will be explored by the European Space Agency JUpiter ICy Moons Explorer (JUICE) Mission. The icy surfaces of Ganymede, as well as Europa and are objectives of JUICE, in order to search for general geophysical features, but especially the search for biomarkers - the question of habitability - will be high amongst the mission priorities.
\end{abstract}

\section{Lake Vostok}

From the point of view of the possibility of the existence of life on Europa, we should consider a lake called Vostok, which is the largest of about 80 subglacial lakes in Antarctica. Its surface is of approximately $14,000 \mathrm{~km}^{2}$ and its volume is $1,800 \mathrm{~km}^{3}$. Indeed this Ontario-sized lake in Eastern Antarctica is also deep, with a maximum depth of $670 \mathrm{~m}$. On the other hand, from the point of view of microbiology, the habitatanalogue provided by Lake Vostok for the Europa environment seems appropriate (Chela-Flores, 2001). At the time of writing the ice above the lake has been cored to a depth of over 3,600 m, stopping just over $100 \mathrm{~m}$ over the surface of the lake itself. This work has revealed great diversity of single-celled organisms: yeast, actinomycetes, mycelian fungi (which remain viable for almost 40,000 years), diatoms, and most interestingly, 200,000 year old bacteria. Besides it appears that water temperatures do not drop too far below zero centigrade, with the possibility of geothermal heating raising the temperatures above this level.

Extrapolation of data retrieved from work deep in the ice core to the lake itself, implies that Lake Vostok may support a microbial population, in spite of the fact that 
that large volume of water has been isolated form the atmosphere for over one million years (Priscu et al., 1999). We shall discuss the possibility of the existence of Europan microbes within a liquid water environment sealed by a frozen surface, which is by now known in great detail with the help of the Galileo Mission (1995-2003).

Bacterial density is found to be two to seven-fold higher in accretion ice than in the overlying glacial ice. This implies that Lake Vostok is a source of bacterial carbon beneath the ice sheath (Dudeja et al., 2010). Phylogenetic analysis of the amplified small subunit ribosomal ribonucleic acid (rRNA) gene sequences in this accretion ice has revealed the presence of alphaproteobacteria, betaproteobacteria and gammaproteobacteria (Christner et al., 2006). With few exceptions, all other characterized species of the deltaproteobacteria are strict anaerobes that respire via the reduction of electron acceptors, such as sulfate, elemental sulfur, iron (III) and Mn (IV) (Lovley et al., 1995).

These bacterial communities are diverse and physically associated. Such ecosystems lead to fundamental questions regarding the physiology and metabolism of several microorganisms. Prominent amongst these microbes we have deltaproteobacteria and betaproteobacteria. Deltaproteobacteria are phylogenetically linked with sulfate bacterial reduction, SBR (Shen and Buick, 2004). Detailed analysis on accreted ice has shown that bacterial cells are often associated with organic and inorganic particles (Priscu et al., 1999), implying that a portion of cells within the lake water are not free living. Similar results have been reported for the permanently ice-covered, lakes in the dry valleys (Lisle and Priscu, 2004).

Lake Vostok and its relevance for astrobiology has been extensively reviewed (Christner et al., 2006; Priscu et al., 2003). It has been estimated that the youngest water is at least 400,000 years old. It is a window into life forms and climates of primordial eras. Lake Vostok is the largest of more than 140 subglacial lakes (Siegert et al., 2005). The zone of ice layer up to $3,309 \mathrm{~m}$ (referred to as I), and the layer between 3,310 to $3,509 \mathrm{~m}$ (zone II) provide detailed information about the paleoclimate record spanning during the last 420,000 years.

The basal portion of the ice core from 3,539 to $3,623 \mathrm{~m}$ has many features differing from overlying glacial ice and its geochemical composition indicates that it represents actual lake water that has accreted (i.e., frozen) to the underneath of ice sheet. Despite extremely cold air temperatures above the ice (an average of $-55{ }^{\circ} \mathrm{C}$ ), liquid water is stable in the lake owing to the combined effect of background geothermal heating, the insulating properties of the overlying icy sheet, and adiabatic lowering of the freezing point (Siegert et al., 2003). Lake Vostok appears to be harboring hydrothermal vents beneath the water surface. This is suggestive of what may be occurring on Europa. The circulation of pure water in Lake Vostok will be driven by the differences between the density of meltwater and lake water.

Geothermal heating will warm the bottom water to a temperature higher than that of the upper layers. The water density will decrease with increasing temperature resulting in an unstable water column. This leads to vertical convective circulation in the lake, in which cold meltwater sinks down the water column and water warmed by geothermal heat ascends up the water column (Siegert et al., 2001). Similarly, Europa may also have geothermally-heated warm water under its ice-crust. Processes of the type that occur in Lake Vostok may be taking place on Europa, where biogenic sulfur may be reaching the surface. 


\section{Perennially ice-covered lakes in Antarctica and microbial mats}

Microorganisms constitute the major part of all life on Earth, and they are mainly organized in microbial mats and into biofilms. For this reason the description of different aspects of microbial mats that are fundamental for our deeper understanding of a major cross-section of microbiology in general, and especially for astrobiology. Amongst the multiple implications of the study of microbial mats emerges the understanding of the early Earth, before multicellularity evolved. Microbial mats may help us to understand the possibility of life elsewhere in our own solar system, such as on Europa, Mars, Enceladus and Titan. Indeed, microbial mats are ubiquitous in extreme environments: at high and low temperatures; in hypersaline bodies of water such as the Dead Sea; in hot springs, where they not only survive, but thrive as exemplified by the startling colored microbial mats that live in Yellowstone National Park. Microbial mats are also present in volcanic vents on the ocean floor, called black smokers. Other environments suitable for microbial mats are deserts and, specifically the Dry Valleys of Antarctica in the McMurdo region that is traversed by striking glaciers. The British explorer Sir Robert Scott discovered the Dry Valleys in 1905 (cf., Table 1 taken from Doran et al., 1994; Wharton et al., 1983; Parker et al., 1982).

TABLE 1: Statistics of the Dry Valleys lakes in Antarctica.

\begin{tabular}{|c|c|c|c|}
\hline Lake or pond & $\begin{array}{l}\text { Maximum depth } \\
\text { (meters) }\end{array}$ & $\begin{array}{l}\text { Elevation (meters } \\
\text { above sea level) }\end{array}$ & $\begin{array}{l}\text { Lake type and } \\
\text { Morphology of mats }\end{array}$ \\
\hline Lake Fryxell & 18 & 17 & $\begin{array}{l}\text { Perennial ice cover; } \\
\text { liquid water, MM, ICM, } \\
\text { FM, CLM, APRM, } \\
\text { ANPRM }\end{array}$ \\
\hline Lake Hoare & 34 & 73 & $\begin{array}{l}\text { Perennial ice cover; } \\
\text { liquid water, MM, ICM, } \\
\text { FM, CLM, APRM, } \\
\text { ANPRM, PM }\end{array}$ \\
\hline Lake Vanda & 69 & 123 & $\begin{array}{l}\text { Perennial ice cover; } \\
\text { liquid water, MM, ICM, } \\
\text { FM, CLM, APRM, } \\
\text { ANPRM }\end{array}$ \\
\hline Don Juan Pond & $0.1-2$ & 116 & Ice-free \\
\hline Lake Chad & 1 & 58 & $\begin{array}{l}\text { Perennial ice cover, } \\
\text { liquid water, MM, ICM, } \\
\text { FM, CLM, PRM }\end{array}$ \\
\hline Lake Bonney & 40 & 57 & $\begin{array}{l}\text { Perennial ice cover, } \\
\text { liquid water, CLM }\end{array}$ \\
\hline
\end{tabular}

MM: Molecular Mats, ICM: Intercellar Mats, FM: Floating Mats, CLM: Columnar Mats, PRM: Prostate Mats, APRM: Aerobic Prostate Mats, PM: Pinnacle Mats, ANPRM: Anaerobic Prostate Mats. 
Some of the most interesting lakes in this region are permanently covered by ice. These extraordinary environments present us with an ideal window to glance at significant events that are relevant for ancient life, and even for paleolimnology that is suggestive of the possible perseverance of life on Mars in an earlier Eden-like epoch.

From the point of view of geology and microbiology, some of the best studied frozen lakes are in the Taylor Valley, namely Lake Fryxell and Lake Hoare. Further north, in the Wright Valley, Lake Vanda is also remarkable for its biota. Amongst the microbial mats that are permanently thriving in the frozen lakes there are examples of both prokaryotes and eukaryotes (cf., Table 2).

TABLE 2: Microorganisms living in the Dry Valleys lakes, Antarctica.

\begin{tabular}{|c|c|c|}
\hline Organism & Domain & Habitat \\
\hline Cyanobacteria & Bacteria & Lakes Chad, Fryxell and Vanda \\
\hline Leptothrix & Bacteria & Lakes Fryxell and Hoare \\
\hline Achronema & Bacteria & Lakes Fryxell and Hoare \\
\hline Clostridium & Bacteria & Lakes Fryxell and Hoare \\
\hline $\begin{array}{l}\text { Chlamydomonas subcaudata } \\
\text { (Phylum Chlorophyta) }\end{array}$ & Eucarya & $\begin{array}{l}\text { Lakes Bonney (east lobe) } \\
\text { and Hoare }\end{array}$ \\
\hline $\begin{array}{l}\text { Diatoms } \\
\text { (Phylum Bacillariophyta) }\end{array}$ & Eucarya & $\begin{array}{l}\text { Lakes Bonney, Chad, Fryxell, Hoare anc } \\
\text { Vanda }\end{array}$ \\
\hline Bryum cf. algens (a moss) & Eucarya & Lake Vanda \\
\hline
\end{tabular}

Besides, some of the most interesting geologic paleoindicators for reconstructing the history of these lakes are stromatolites. In the Dry Valleys these structures consist of various species of cyanobacteria, such as Phormidium frigidum Fritsch, a prokaryote that forms the matrix of most mat types (Wharton et al, 1983). Modern organisms analogous to ancient life are to be found in the Dry Valley lakes.

What is most significant is that single-celled eukaryotes are amply represented in this Antarctic biota. Amongst the related paleoindicators that have been found are diatom frustules, cyst-like structures, most likely of crysophycean origin have also been identified. These intriguing lakes contain various taxa of planktonic and benthic microorganisms. These environments are dominated by lower life forms inviting us to search for biomarkers of an earlier biota since grazing, for instance, is totally absent (Doran et al., 1994). Microbial mats in lake Bonney, Chad, Fryxell, Hoare and Vanda have been thoroughly documented, especially since the 1980s. For instance, in these environments microbial mats are known to include not only the above-mentioned cyanobacteria, but also heterotrophic bacteria, eukaryotic algae (mainly diatoms) and fungi (Baublis et al., 1991). There are some dinoflagellates Gymnodinium and 
Glenodinium in Lake Fryxell, where in addition protozoan taxa were associated with the algal mats (Cathey et al., 1981).

The existence of these permanently frozen lakes add an extra bonus to our working model of the Europan Ocean. Modern organisms analogous to the early biota of the Earth are to be found in the Dry Valley lakes (Simmons et al., 1979; Parker et al., 1980; Parker and Wharton, 1985). Most importantly, single celled eukaryotes are amply represented in this biota. In Table 3 we summarize some of the organisms known to inhabit in these lakes (Doran et al., 1994; Wharton et al., 1983; Parker et al., 1981, 1982; Ellis-Evans and Wynn-Williams, 1996).

TABLE 3: A few examples of eukaryotes present in Antarctica.

\begin{tabular}{lll}
\multicolumn{1}{c}{ Organism } & \multicolumn{1}{c}{ Domain } & \multicolumn{1}{c}{ Habitat } \\
\hline Diatom shells & $\begin{array}{l}\text { Eucarya } \\
\text { (Bacillariophyta) }\end{array}$ & $\begin{array}{l}\text { Lake Vostok } \\
\text { (ice core, at depth of 2375m) }\end{array}$ \\
Caloneis ventricosa & $\begin{array}{l}\text { Eucarya } \\
\text { (Bacillariophyta) }\end{array}$ & $\begin{array}{l}\text { Lakes Chad, Fryxell, Hoare and } \\
\text { Vanda }\end{array}$ \\
Hantzschia amphioxys & $\begin{array}{l}\text { Eucarya } \\
\text { (Bacillariophyta) }\end{array}$ & $\begin{array}{l}\text { Lakes Fryxell, Hoare and Vanda } \\
\text { Navicula } \\
\text { cryptocephala }\end{array}$ \\
$\begin{array}{l}\text { Eucarya } \\
\text { (Bacillariophyta) }\end{array}$ & $\begin{array}{l}\text { Lakes Bonney, Fryxell, Hoare and } \\
\text { Vanda }\end{array}$ \\
$\begin{array}{l}\text { Subcaudata } \\
\text { Tetracystis } \text { sp. }\end{array}$ & $\begin{array}{l}\text { Eucarya } \\
\text { (Chlorophyta) }\end{array}$ & Lakes Bonney and Hoare \\
Eeast & $\begin{array}{l}\text { (Chlorophyta) } \\
\text { Eucarya } \\
\text { (Ascomycota) }\end{array}$ & Lakes Fryxell, Hoare and Vanda \\
\hline
\end{tabular}

The permanently ice-covered lakes of the McMurdo Dry Valleys present a legitimate earthly analog to putative Europan ecosystems. The presence of dissolved organic carbon (derived from microbial mats, algae and bacteria), sulfate reduction (one of the most dominating process responsible for organic matter oxidation) and the adaptation of microorganisms (thriving on either oxygenic or anoxygenic photosynthesis) to low temperatures and low light conditions are the three most important analogies to look for while searching for extraterrestial life or life sustaining environments in Europa.

In addition, the influence of saline conditions on microbial life in dry valley lakes particularly Blood Falls (a subglacial iron-rich brine) and Don Juan Pond (one of the coldest, saltiest water bodies on earth) is also interesting since in such a system a microbial consortium facilitates a catalytic sulfur cycle which is a result of limited carbon supply because of the absence of contemporary photosynthesis. (Mikucki et al., 
2010). Such systems demonstrate the possibility of biogeochemical process capable of accumulating iron (Fe (II)) despite the presence of an active sulfur cycle. This alternative sulfur cycle could be important if the ocean beneath the surface of Europa contains iron (Fe(III)) (Mikucki, 2009).

\section{Microbially-produced patches in Antarctica. Can they be produced on Europa too?}

The extremophiles that are trapped in microbial mats may also be living under the Taylor Glacier in the Taylor Valley, a region that is bounded by the Ferrar Glacier and the Asgard Range. These microbes probably lived in the ocean at one time, but when the floor of the Dry Valleys rose more than a million years ago, the glacier covered seawater when it advanced and trapped the microorganisms in pockets of water. An intriguing feature, named Blood Falls, suggests the presence of microbial mats underneath the Taylor glacier. The name is due to the resemblance with a blood-red color waterfall at the glacier's extreme end. This coloring is analogous to the colored microbial mats that live in the hot springs of the Yellowstone National Park.

Isotopic measurements of sulfate, water, carbonate, and ferrous iron and gene analyses imply that a microbial consortium facilitates a catalytic sulfur cycle that may be analogous to the metabolic events that may sustain life elsewhere in the Solar System (Mikucki et al., 2009). This is especially relevant to the icy satellites of the outer Solar System, including Europa, where sulfur patches were discovered by the Galileo Mission (1995-2003). These stains on the icy surface of the Jovian satellite are suggestive of chemosynthetic products of metabolism. In addition, underneath $4 \mathrm{~km}$ of ice in that continent there is a subsurface lake that presumably contains living microbes. This hypothesis has been confirmed, since microorganisms have been found from accretion ice retrieved from ice 3590 meters below Vostok Station (Priscu et al., 1999). Extrapolation of the data to the lake itself, known as Lake Vostok, may support a microbial population, despite more than $10^{6}$ years of isolation from the atmosphere. These examples are just the "tip of the iceberg", since by means of ice-penetrating radio-echo sounding surveys we have discovered the existence of about 280 subglacial lakes, most of them being located under the East Antarctic ice sheet (Smith et al., 2009).

All the above facts encourage the search for biogenicity. Our main interest is the search for biosignatures on Europa on the sulfur patches discovered by the Galileo mission (Singer, 2003; Bhattercherjee and Chela-Flores, 2004; Chela-Flores and Kumar, 2008; Chela-Flores et al., 2009).

The Galileo Mission discovered the sulfur patches of non-ice elements on Europa's icy surface. These patches have been inferred and confirmed over a twenty-year period. They match the distribution of an ultraviolet absorber that was suggested all the way back by the Voyager data (McEwen, 1986). The New Horizons Mission on its way to Pluto has confirmed the patches of non-ice elements (Grundy et al., 2007). Based on combined spectral reflectance data from the Solid State Imaging experiment (SSI), the Near Infrared Mass Spectrometer (NIMS) and the Ultraviolet Spectrometer (UVS), it has been argued that the non-water ice materials are endogenous in three diverse, but significant terrains (Fanale et al., 1999). Effusive cryovolcanism is clearly one possible 
endogenous source of the non-water-ice constituents of the surface materials (Fagents, 2003). The most striking feature of the non-water surficial elements is certainly their distribution in patches. Implantation would be expected to produce a more uniform surface distribution if the source were ions from the Jovian plasma; it may be argued that if the plasma from the magnetosphere were responsible for the sulfur distribution, some geologic process has to be invoked to allow for a non-uniform distribution (Carlson et al., 1999).

Alternatively, the sulfurous material on the surface may be endogenous. In other words, the cryovolcanism on Europa would be from the bottom of the global ocean, more like the "black smokers" that are found on the Earth seafloor.

\section{Discussion}

On the strength of our Antarctic models sketched above, we may assume that on Europa the presence of hydrothermal activity at the interface of the silicate core and the ocean can provide a variety of chemicals playing a role in sustaining microbial life at the ocean floor. To search for life several options are in principle available. Astrobiological exploration should not be restricted to the remote observation of the surface for three main reasons (Gowen et al., 2011):

(1) The likely habitable environments are in the subsurface, where liquid water may be present.

(2) The surface has an intense radiation environment where many materials, including organic molecules, may not survive unaltered for a long time. If the aqueous reservoirs are linked with the surface, by fractures for instance, materials indicative of the habitability may ascend from the interior. But exposed materials will be affected and may lose the signatures from the potential habitable environment. So, remote measurements will be from secondary materials, modified on the surface from the original conditions at the interior aqueous reservoirs.

(3) The concentration of biosignatures at the surface may not be sufficient for remote detection.

We discuss some of the possible lines of research. Firstly, the Antarctic lakes are a starting point for the technology of submersibles: Mapping Antarctica's West Lake Bonney, is an ongoing project. This is a two-and-a-half mile long, one-mile wide, 130 foot-deep lake located in McMurdo Dry Valleys. Bonney has a permanent ice-cover 12 to 15 feet deep (cf., Table 1 for a comparison with other dry-valley lakes). Earlier we had envisaged submersible technology, under the name of cryobot-hydrobot coupled probes (Horvath et al., 1998). In spite of the great challenge in proceeding in this direction, the more recent NASA project "ENDURANCE" is providing insights in completely independent light submersibles to map in 3-D the geochemistry and biology of ice-covered lakes. (It is an acronym for Environmentally Non-Disturbing Under-ice Robotic Antarctic Explorer.) The nearly spherical submersible is about 2 meters (6.5 feet) in diameter and in air weighs more than 1300 kilograms (about 1.5 tons). Clearly for the eventual use in the Jovian System, this concept has to go through several stages 
of miniaturization. The Endurance Project is led by Peter Doran with Bill Stone (caver) and John Priscu among the co-investigators.

Secondly, closer to our time and the next mission being planned, the biogenic hypothesis can be subject to a more feasible experimental test: We may look for cellular life (a third, simpler and possibly more feasibble option will be discussed below). In this case some penetration tool (beyond the simple effect of the gravitational force) has to be added to the penetrator. One option that has received attention in the literature is that of a mole-like thermal drill designed to cut through the icy surface. Such a device would use heat to melt through the ice and a rotating drill blades to clear away rocky material. The drill would be nestled inside a larger penetrator that would burrow itself into Europa's icy surface To search for signs of life on Europa the penetrator may have to go deeper into the surface ice, because space weather conditions erase any cellular traces in the top layer. The drill would be tethered to the penetrator by a communication cable, which would allow data to be sent to the instruments in the penetrator, to be later beamed up to an orbiter (Weiss et al., 2008; 2011).

Finally, biogenicity may be subject to a simpler test. If we do not focus on cellular life, but rather of its metabolic effects in the fractionation of sulfur, we can to exploit the Galileo Mission remarkable discovery that Europa's non-ice surficial elements. They were were found to be widespread, patchy and, most likely, endogenous. For probing the Europan patches the most appropriate technology is the penetrator. This approach consists of small projectiles that can be delivered at high velocity to reach just beneath the surface of planets or their satellites for probing samples of surficial chemical elements, amongst other investigations. The recent interest in lunar science in the UK has led to the development of penetrators by the UK Penetrator Consortium (Gowen et al., 2009).

These instruments can have payloads that would allow a variety of measurements on the Jovian satellite surfaces for the search of biomarkers on Europa and Ganymede. Whilst orbiting instruments can further investigate the nature of Europa's surface and interior, currently only in situ instruments offer the realistic possibility to detect any evidence of life. The rough surfaces and extreme cold, together with an extreme radiation environment mean that Europa is a challenging, but not impossible, object for in situ measurements. Penetrators of relatively low mass $(\sim 5-15 \mathrm{~kg})$ are better suited to these conditions than a soft lander, since they are buried on impact in the near-surface regolith, thereby automatically accessing areas subjected to a significantly reduced radiation flux, whilst easing radiation shielding requirements (Gowen et al, 2010).

We argue that penetrators should be inserted in orbital probes in the future exploration of Jupiter's System. The European Space Agency JUpiter ICy Moons Explorer (JUICE) Mission consists of a spacecraft operating in the Jovian system with the Jupiter Ganymede Orbiter (JGO) that will execute a coordinated exploration of the Jupiter System, including the Galilean satellites Europa and Callisto, before settling into orbit Ganymede (Dougherty et al., 2011). JGO will carry several complementary instruments to map the Jovian magnetosphere and its interactions with the Galilean satellites, and characterize water oceans beneath the ice shells of Europa and Ganymede (Bland et al., 2009, Chela-Flores, 2010).

There are alternative views on the effect of space weather on the radiation-induced Scycles produced on the surficial molecules on Europa; but $\mathrm{S}$ is common to both interpretations (Carlson et al., 1999; McCord et al., 1999). The largest known S- 
fractionations are due to microbial reduction, and not to thermochemical processes. Besides, sulfate abiotic reductions are generally not as large as the biogenic ones (Kiyosu and Krouse, 1990). From experience with a natural population, this type of biota is able to fractionate efficiently $\mathrm{S}$-isotopes up to $\delta^{34} \mathrm{~S}$ of $-70 \%$ (Wortmann et al., 2001). Dissimilatory sulfate reducers are ubiquitous on Earth, producing the largest fractionations in the sulphur stable isotopes. These microbes are widely distributed in terrestrial anoxic environments, especially in the Antarctic ecosystems described in the present chapter.

Europa's surface is an extremely hostile environment, as a result of space weather, namely the constant exposure to Jupiter's intense radiation belts. The topmost ice layer is subject to harsh radiation, but changes other than chemical reactions (photolysis, radiolysis) are not to be taken into account since, for instance, there is no high-energy (several gigaelectron volt, $\mathrm{GeV}$ ) deep-inelastic scattering that would change the nuclear identity of the atomic components of the surficial molecules participating in the abovementioned S-cycles. Meteoroid gardening might lead to the contamination of the upper surface 1-2 meters with regolith (Cooper et al., 2001). This would require penetrating deeper than this depth in order to reach pristine material, which would be challenging, even for penetrators. However, since sulfur processing by bacteria may lead to such radical and extreme depletions of ${ }^{34} \mathrm{~S}$ compared to exogenous sulfur, even if some of the contaminated surface by the gardening process contains non-biological sulfur, and penetrators do not reach the above-mentioned depths $(1-2$ meters $)$, robotic massspectrometry analysis of the non-water ice elements would identify biologically processed sulfur (for example, $\delta S^{34}$ reaching over -(50 to 60$) \%$ ).

Consequently, they are the most evident candidates for the microorganisms populating a habitable Europan ecosystem. Microbial fractionation of stable S-isotopes argue in favor of penetrators for surveying the surface of not only Europa, but also Ganymede, where surficial sulfur has been detected (McCord et al., 1997). According to our hypothesis we predict that penetrators (supplied with mass spectrometry) should yield different results for fractionated sulfur. The icy patches on Europa should give substantial depletions of ${ }^{34} \mathrm{~S}$ if penetrators supported the JUICE Mission, while measurements on Ganymede hopefully with penetrators on JGO, should give significantly lower values for the depletion of ${ }^{34} \mathrm{~S}$. As the largest of the Galilean satellites lacks an ocean-core interface, then according to our hypothesis it would not be able to support life (Chela-Flores, 2010).

These diverging results - large minus $\delta^{34} S$ for Europa, and small minus $\delta^{34} S$ for Ganymede-would provide a clear test for the hypothesis that a habitable ecosystem has emerged on Europa. The test is within reach of available technology for planning the eventual penetrator payload. From what we have said in this chapter the Antarctic dry valley lakes, as well as the many subglacial lakes, especially Vostok, and more recently Lake Concordia are excellent models for the possible ecosystems that we are unable to probe directly elsewhere in the Solar System. It seems reasonable from the point of view of instrumentation and costs that we should insist that the payloads for JGO include penetrators capable of doing mass spectrometry. 


\section{References}

Baublis J. A, Wharton, R. A. Jr., Volz P. A. (1991) Diversity of micro-fungi in an Antarctic dry valley, J. Basic Microbiol. 31(1): 3-12.

Bhattacherjee, A. B and Chela-Flores, J. (2004) Search for bacterial waste as a possible signature of life on Europa. In "Life in the Universe", J. Seckbach, J. Chela-Flores, T. Owen and F. Raulin (eds.) Cellular Origin and Life in Extreme Habitats and Astrobiology, 7. Springer: Dordrecht, The Netherlands, pp. 257-260.

Bland, M. T., Showman, A. P. and Tobie, G. (2009) The orbital-thermal evolution and global expansion of Ganymede. Icarus 200: 207-221.

Carlson, R. W. , Johnson R. E. And Anderson, M. S. (1999) Sulfuric Acid on Europa and the Radiolytic Sulfur Cycle. Science 286: 97-99.

Cathey, D. D., Parker, B. C., Simmons Jr., G. M.,. Yongue Jr., W. H and Van Brunt, M. R. (1981) The microfauna of algal mats and artificial substrates in Southern Victoria Land lakes of Antarctica, Hydrobiologia 85: 3-15.

Chela-Flores, J. (2001) The New Science of Astrobiology From Genesis of the Living Cell to Evolution of Intelligent Behavior in the Universe. Kluwer Academic Publishers: Dordrecht, The Netherlands (279 pp.).

Chela-Flores, J. (2010) Instrumentation for the search of habitable ecosystems in the future exploration of Europa and Ganymede. International Journal of Astrobiology, 9 (2): 101-108 (Copyright holder: Cambridge University Press: 2010). http://www.ictp.it/ chelaf/jcf_IJA_2010.pdf

Chela-Flores, J., Bhattacherjee, A. B., Dudeja, S., Kumar, N. and Seckbach, J. (2009) Can the biogenicity of Europa's surfical sulfur be tested simultaneously with penetrators and ion traps? Geophysical Research Abstracts, Vol. 11, EGU2009-0, 2009, EGU General Assembly 2009. The Austria Centre, Vienna, 22 April.

Chela-Flores, J. and Kumar, N. (2008) Returning to Europa: Can traces of surficial life be detected? International Journal of Astrobiology 7(3): 263-269 (Cambridge University Press).

Christner, B.C., Roysto-Bishop, G., Foreman, C.M., Arnold, B.R., Tranter, M., Welh, K.A., Lyons, W.B., Tspain A.I., Studinger M., and Priscu J.C. (2006) Limnological conditions in subglacial Lake Vostok, Antarctica. Limnology and Occeanography 51: 2485-2501.

Cooper, J. F., Johnson, R.E., Mauk, B. H., Garrett, H. B., and Gehrels N. (2001) Energetic ion and electron radiation of the icy Galelian satellites. Icarus 149: 133159.

Doran, P.T., Wharton, Jr., R.A., and Berry Lyons, W. (1994) Paleolimnology of the McMurdo Dry Valleys, Antarctica. J. Paleolimnol. 10: 85-114.

Dougherty, M. K., Grasset, O., Bunce, E., Coustenis, A., Titov, D.V., Erd, Ch., Blanc, M., Coates, A.J., Coradini, A., Drossart, P., Fletcher, L., Hussmann, H., Jaumann, R., Krupp, N., Prieto-Ballesteros, O., Tortora, P., Tosi, F., Van Hoolst, T., Lebreton, J.- P. (2011) JUICE (JUpiter ICy moon Explorer): a European-led mission to the Jupiter system. In: EPSC Abstracts Vol. 6, EPSC-DPS2011-1343-1, European Planetary Science Congress-Division for Planetary Sciences of the American Astronomical Society Joint Meeting.

Dudeja, S., Bhattacherjee, A. B. and Chela-Flores, J. (2010). Microbial mats in Antarctica as models for the search of life on the Jovian moon Europa. In: J. 
Seckbach and A. Oren (eds.) Microbial Mats, COLE series, Springer, Dordrecht, The Netherlands pp. 543-561.

http://www.ictp.it/ chelaf/Dudeja.pdf

Ellis-Evans, J. C. and Wynn-Williams, D. (1996) A great lake under the ice. Nature 381: 644 - 646.

Fagents, S. A. (2003) Considerations for the Effusive Cryovolcanism on Europa: The Post-Galileo Perspective. J. Geophys. Res. 108, No. E12: 5139.

Fanale, F. P., Granahan, J. C., McCord, T. B., Hansen, G.,.Hibbitts, C. A., Carlson, R., Matson, D., Ocampo, A., Kamp, L., Smythe, W., Leader, F., Mehlman, R., Greeley, R., Sullivan, R., Geissler, P., Barth, C., Hendrix, A., Clark, B., Helfenstein, P., Veverka, J., Belton, M.1 J. S., Becker, K., Becker, T., and the Galileo instrumentation teams NIMS, SSI, UVS (1999) Galileo's Multiinstrument Spectral View of Europa's Surface Composition. Icarus 139: 179-188.

Gowen, R., Smith, A., Ambrosi, R., Ballesteros, O. P., Barber, S., Barnes, D., Braithwaite, C., Bridges,J., Brown, P., Church, P., Collinson,G., Coates,A., Collins, G., Crawford, I., Dehant, V., Dougherty,M., Chela-Flores, J., Fortes,D., Fraser, G., Yang, Y., Grande,M., Griffiths,A., Grindrod,P., Gurvits,L., Hagermann,A., Hoolst,T.V., Hussmann,H., Jaumann,R., Jones,A., Jones,G., Joy,K., Karatekin, O., Kargl,G., Macagnano, A., Mukherjee, A., Muller, P., Palomba, E., Pike, T., Proud, B., Pullen,D., Raulin, F., Richter, L., Ryden, K., Sheridan, S., Sims,M., Sohl,F., Snape,J., Stevens,P., Sykes,J., Tong,V., Stevenson,T., Karl, W., Wilson,L., Wright,I. and Zarnecki, J. (2009) Looking for Astrobiological Signatures with Penetrators on Europa. In: Physical and Engineering Sciences Exploratory Workshops, W08-115, co-funded by Life, Earth and Environmental Sciences: Biosignatures On Exoplanets; The Identity Of Life, 22-26 June 2009, Mulhouse, France.. http://www.ictp.it/ chelaf/ESFsummary.pdf

Gowen, R. A., Smith, A., Fortes, A.D., Barber, S., Brown, P., Church, P., Collinson, G., Coates, A. J., Collins, G., Crawford, I. A., Dehant, V., Chela-Flores, J., Griffiths, A. D., Grindrod, P.M., Gurvits, L.I., Hagermann, A, Hussmann, H., Jaumann, R., Jones, A.P., Joy. A. Sephton, , K.H., Karatekin, O., Miljkovic, K., Palomba, E., Pike, W.T., Prieto-Ballesteros, O, Raulin, F., Sephton, M. A., Sheridan, M S., Sims, M., StorrieLombardi, M. C., Ambrosi, R., Fielding, J, Fraser, G., Gao, Y., Jones, G. H., Kargl, Karl, W. J., Macagnano, A., Mukherjee, A., Muller, J.P., Phipps, A., Pullan, D., Richter, L., Sohl, F., Snape, J., Sykes, J., Wells, N. (2011) Penetrators for in situ subsurface investigations of Europa. Adv. Space Res. 48: 725-742.

Grasset, O., Lebreton, J.-,P., Blanc, M., Dougherty, M., Erd, C, Greeley, R., Pappalardo, B. and the Joint Science Definition Team (2009) The Jupiter Ganymede Orbiter as part of the ESA/NASA Europa Jupiter System Mission (EJSM). EPSC Abstracts 4, EPSC2009-784, European Planetary Science Congress.

Grundy, W. M., Buratti, B. J., Cheng, A. F., Emery, J. P., Lunsford, A.; McKinnon, W. B., Moore, J. M., Newman, S. F., Olkin, C. B., Reuter, D. C.; Schenk, P. M., Spencer, J. R., Stern, S. A., Throop, H. B., Weaver, H. A. (2007) New Horizons Mapping of Europa and Ganymede. Science 318: 234-236.

Horvath, J., Carsey, F., Cutts, J. Jones, J. Johnson, E.. Landry, B., Lane, L., Lynch, G., Chela-Flores, J., Jeng, T-W. and Bradley, A. (1997) Searching for ice and ocean biogenic activity on Europa and Earth. Instruments, Methods and Missions for Investigation of Extraterrestrial Microorganisms, (R.B. Hoover, ed.), Proc. SPIE 
3111: 490-500.

http://www.ictp.it/ chelaf/searching_for_ice.html

Kiyosu, Y. and Krouse, H.R. (1990) The role of organic acid in the abiogenic reduction of sulfate and the sulfur isotope effect. Geochemical Journal 24: 21-27.

Lisle, J. and Priscu, J. (2004) The occurrence of lysogenic bacteria and microbial aggregates in the lakes of the McMurdo Dry Valleys, Antarctica. Microbial Ecology 47: 427-439.

Lovley, D.R., Phillips E.J.P., Lonergan D.J., and Widman, P.K. (1995) Fe(III) and S (0) reduction by Paleobacter carbinolicus. Appl. Environ. Microbiol. 61: 2132-2138.

McCord, T. B., Carlson, R. W., Smythe, W. D., Hansen, G. B., Clark, R. N., Hibbitts, C. A., Fanale, F. P. J., Granahan, C., Segura, M., Matson, D. L., Johnson, T. V. and Martin P. D. (1997) Organics and Other Molecules in the Surfaces of Callisto and Ganymede. Science 278: 271 - 275.

McCord, T. B., Hansen, G. B., Matson, D. L., Johnson, T. V., Crowley, J. K., Fanale, F. P., Carlson, R. W., Smythe, W. D., Martin, P. D., Hibbitts, C. A., Granahan, J. C., Ocampo, A., and the NIMS team (1999) Hydrated salt minerals on Europa's Surface from the Galileo near-infrared mapping spectrometer (NIMS) investigation. $J$. Geophys. Res. 104: 11827-11851.

McEwen, A. (1986) Exogenic and endogenic albedo and color patterns on Europa. $J$. Geophys. Res. 91: 8077-8097.

Mikucki, J. A., Pearson , A., Johnson, D. T, Turchyn, A. V., Farquhar, J., Schrag, D. P., Anbar, A. D., Priscu, J. C. and Lee, P. A. (2009) A contemporary microbially maintained subglacial ferrous "ocean", Science, 324: 397-400.

Mikucki, J. , Lyons, B., Hawes, I., Lanoil, B.D. and Doran, P. T. (2010) Saline lakes and ponds in the McMurdo Dry Valleys: ecological analogs to martian paleolake environments. In: Life in Antarctic Deserts and Other Cold Dry Environments: Astrobiological Analogs. eds. Peter T. Doran, W. Berry Lyons and Diane M. McKnight. Cambridge University Press, 160-194.

Parker, B.C., and Wharton, R.A. (1985) Physiological ecology of blue-green algal mats (modern stromatolites) in Antarctic oasis lakes. Archiv fuer Hydrobiologie. Suppl. 71: 331-348.

Parker, B.C., Simmons G.M., Jr., Seaburg, K.G., and Wharton, R.A., Jr. (1980) Ecological comparisons of oasis lakes and soils. Antarct. J. U. S. 15: 167-170.

Parker, B. C., Simmons, Jr., G. M., Gordon Love, F., Wharton, Jr., R.A. and Seaburg, K. G. (1981) Modern Stromatolites in Antarctic Dry Valley Lakes. BioScience 31: 656661.

Parker, B.C., Simmons, Jr., G.M., Wharton, Jr., R.A., Seaburg, K.G., and Gordon Love, F. (1982) Removal of organic and inorganic matter from Antarctic lakes by aerial escape of bluegreen algal mats. J. Phycol. 18: 72-78.

Priscu, J.C., Adams, E.E., Lyons, W.B., Voytek, M.A., Mogk, D.W., Brown, R.L., McKay, C.P., Takacs, C.D., Welch, K.A., Wolf, C.F., Krishtein, J.D., and Avci, R. (1999) Geomicrobiology of subglacial ice above Lake Vostok, Antarctica. Science 286: 2141-2144.

Priscu, J.C., Bell, R.E., Bulat, S.A., Ellis-Evans, C.J., Kennicutt, M.C., Lukin, V.V., Petit, J.-R., Powell, R.D., Siegert, M.J., and Tabacco, I. (2003) An international plan for Antarctica subglacial lake exploration. Polar Geogr. 27: 69-83. 
Shen, Y. and Buick, R. (2004) The antiquity of microbial sulfate reduction. EarthScience Reviews, 64: 243-272.

Siegert, M.J., Ellis-Evans, J.C., Tranter, M., Mayer, C., Petit, J.R., Salamatin, A., and Priscu, J.C. (2001) Physical, chemical and biological processes in Lake Vostok and other Antarctic subglacial lakes. Nature 414: 603-609.

Siegert, M. J., Tranter M., Ellis-Evans J.C., Priscu, J.C., and Lyons, W.B. (2003) The hydrochemistry of Lake Vostok and the potential for life in Antarctic subglacial lakes. Hydrol. Processes 17: 795-814.

Siegert, M.J., Carter, S., Tabacco, I., Popov S., and Blankenship, D.D. (2005) A revised inventory of Antarctic subglacial lakes. Antarctic Sci. 17: 453-460.

Simmons Jr., G.M., Parker, B.C., Allnut, F.T.C., Brown, D., Cathey, D., and Seaburg, K.G. (1979) Ecological comparison of oasis lakes and soils. Antarct. J. U. S. 14: 181-183.

Singer, E. (2003) Vital clues from Europa. New Scientist Magazine, 2414: 22-23.

Smith, B. E. Fricker, H. A. Joughin, I. R. and Tulaczyk, S. (2009) An inventory of active subglacial lakes in Antarctica detected by ICESat (2003-2008). Journal of Glaciology 55: 573-595.

Weiss, P., Yung, K. L., Ng., T. C., Komle, N., Kargl., G. and Kaufmann, E. (2008) Study of a melting drill head for the exploration of subsurface planetary ice layers. Planetary and Space Science 56:1280-1292.

Weiss, P., Yung, K. L., Koemle, N., Ko, S. M., Kaufmann, E., Kargl, G. (2011) Thermal drill sampling system onboard high-velocity impactors for exploring the subsurface of Europa. Advances in Space Research 48:, Issue 4, 743-754.

Wharton Jr., R.A., Parker, B.C., and Simmons Jr., G.M. (1983) Distribution, species composition and morphology of algal mats in Antarctic Dry Valley lakes. Phycologia 22: 355-365.

Wortmann,U.G., Bernasconi, S.M., and Bottcher, M. E., (2001) Hypersulfidic deep biosphere indicates extreme sulfur isotope fractionation during single-step microbial sulfate reduction. Geology 29: 647-650. 